\title{
Biochemical and Molecular Analysis of Some Commercial Samples of Chilli Peppers from Mexico
}

\author{
Ivonne Guadalupe Troconis-Torres, ${ }^{1}$ Marlon Rojas-López, ${ }^{2}$ César Hernández-Rodríguez, ${ }^{3}$ \\ Lourdes Villa-Tanaca, ${ }^{3}$ Ignacio Eduardo Maldonado-Mendoza, ${ }^{4}$ Lidia Dorantes-Álvarez, ${ }^{1}$ \\ Darío Tellez-Medina, ${ }^{1}$ and María Eugenia Jaramillo-Flores ${ }^{1}$ \\ ${ }^{1}$ Departamento de Ingenieria Bioquimica, Escuela Nacional de Ciencias Biológicas-Instituto Politécnico Nacional, Carpio y Plan de \\ Ayala s/n Col, Casco de Santo Tomás, 11340 Mexico City, DF, Mexico \\ ${ }^{2}$ Centro de Investigacion en Biotecnologia Aplicada, 90700 Exhacienda San Juan Molino Carretera Estatal Tecuexcomac-Tepetitla Km \\ 1.5, TLAX, Mexico \\ ${ }^{3}$ Departamento de Microbiología, Escuela Nacional de Ciencias Biológicas-Instituto Politécnico Nacional, Carpio y Plan de Ayala s/n \\ Col, Casco de Santo Tomás, 11340 Mexico City, DF, Mexico \\ ${ }^{4}$ Departamento de Biotecnología Agrícola, CIIDIR-IPN, Juan de Dios Batíz Paredes 250, Guasave, 81101 Sinaloa, Mexico
}

Correspondence should be addressed to María Eugenia Jaramillo-Flores, jaramillo_flores@hotmail.com

Received 20 December 2011; Revised 1 March 2012; Accepted 6 March 2012

Academic Editor: P. B. Kirti

Copyright ( 2012 Ivonne Guadalupe Troconis-Torres et al. This is an open access article distributed under the Creative Commons Attribution License, which permits unrestricted use, distribution, and reproduction in any medium, provided the original work is properly cited.

\begin{abstract}
The genus Capsicum provides antioxidant compounds, such as phenolics and carotenoids, into the diet. In Mexico, there is a wide diversity of species and varieties of chilli peppers, a fruit which has local cultural and gastronomic importance. In the present study, the relationship of the carotenoid and phenolic profiles with the RAPD fingerprint of three different commercial cultivars of chilli peppers of seven regions of Mexico was investigated. Through RAPD, the species of chilli were differentiated by means of different primers (OPE-18, MFG-17, MFG-18, C51, and C52). The genetic distance found with OPE 18 was in the order of 2.6. The observed differences were maintained when the chromatographic profile of carotenoids, and the molecular markers were analyzed, which suggest a close relationship between carotenoids and the genetic profile. While the chromatographic profile of phenols and the molecular markers were unable to differentiate between genotypes of chilli peppers. In addition, by using infrared spectroscopy and statistical PCA, differences explained by geographic origin were found. Thus, this method could be an alternative for identification of chilli species with respect to their geographic origin.
\end{abstract}

\section{Introduction}

Chilli peppers (Capsicum annuum L.) are used in a multitude of food preparations and are marketed in different regions. The greatest genetic variety of $C$. annuum $\mathrm{L}$. can be found in Mexico, where there are chilli peppers of many different shapes, sizes, and colours [1], and they are among the most frequently consumed products. The genus Capsicum is classified into the family of Solanaceae, which is constituted by 25 wild and 5 domesticated species (C. annuum L., $C$. frutescens L., C. chinense Jacq, C. baccatum Jacq, and $C$. pubescens L.), including more than 200 varieties $[2,3]$. Of these five domesticated species, $C$. annuum $\mathrm{L}$. is the most commonly cultured [4]. Chilli peppers have been object of study mainly due to containing capsaicin, which produces different pungency levels [5], as well as carotenoids and phenolic compounds, which are used as natural pigments and antioxidant agents [6]. Chilli peppers may have different content and profiles of such compounds, depending on the genotype and variety, maturity of the fruit, and the environmental conditions of the cultures [7].

In order to preserve, manage, and improve the different chilli species, the evaluation of the extent of genetic variation within species, as this has now become a fundamental tool in biology and agriculture. Among the main criteria used for that purpose are morphological and molecular markers [8]. 
The RAPD (random amplified polymorphic DNA) method is a widely used technique for molecular marking and is based on the amplification of genomic DNA fragments by using primers of arbitrary nucleotide sequences; which in turn detects polymorphisms that can be employed as genetic markers without previous genetic sequences. In addition to being simple, fast, and low-cost, this method does not require radioactive markers and consumes minimum amounts of DNA [9-11]. However, one of the inconveniences reported about the RAPD technique, since it was published for the first time, is the low reproducibility found mainly in low-intensity bands. The most important factor affecting reproducibility in RAPD analysis is the preparation of the DNA template. Thereby, the differences in the concentration of DNA template between samples are observed as the gain or loss of some bands.

Recently, to improve the results, phytochemical markers have been combined with molecular techniques. Silva et al. [12] correlated the flavonoid content of medicinal plants from Brazil with molecular markers obtained by RAPD, whereas Ercisli et al. (2007-2008) [13, 14] obtained rapid results for evaluation of genotypic diversity and distances by using methyl esters of fatty acids as markers. Previously, the content and composition of fatty acids were tested as taxonomic markers in Hippophae rhamnoides L., showing that these substances, such as linoleic acid, can be used as biochemical markers for this species [15]. On the other hand, Füller et al. [16] analyzed the variability of morphological characteristics as well as the content of phenolic compounds and essential oils in plants from southern Brazil. Moreover, Rotini et al. [17] described the state of preservation of a meadow by comparing the content of phenolic compounds and the RAPDs.

Another essential technique for determining the biological nature of agriculture products is Fourier transforminfrared spectroscopy (FTIR), which is a technique that has been widely employed for food characterization because of several important advantages, such as its nondestructive nature and its capacity to yield structural information that constitutes a molecular fingerprint of the sample. A combination of FTIR and chemometric techniques like principal component analysis (PCA) has been employed as a direct and rapid way to discriminate properties in foods, including geographic origin, adulteration, and quality control [18].

The aim of the present study is to contribute to management and improvement of the different chilli species by determining the relationship between molecular and biochemical markers, such as the content of carotenoids and phenolic compounds among different commercial cultivars of chilli peppers from diverse geographic origins.

\section{Materials and Methods}

2.1. Biological Material. The samples were collected from central and north regions of Mexico (Table 1). Fresh and mature chilli peppers were used for this study. The chilli peppers were considered fresh when the samples presented bright green colour, and smooth, firm texture. The mature specimens were derived from the green samples, by exposure to sunlight and moisture-free storage in the laboratory for 25 to 35 days. The samples were considered mature when the chilli peppers had a bright red, yellow, or orange colour and less firmness and texture. The samples were washed with water and stored at $-70^{\circ} \mathrm{C}$.

2.2. Determination of Fruit Size. Length, width, and weight of the fruits were determined in accordance to the Mexican Official Standard [19]. Briefly, the length was taken from the base to the apex of the fruit without considering the peduncle; the width was measured at the widest part of the chilli pepper; for the weight, an analytical balance was used.

2.3. Determination of Carotenoids. The extraction of carotenoids from the chilli samples was carried out with $2 \mathrm{~g}$ portions of pulp and peel, which were mixed with diatomaceous earth and acetone at $10^{\circ} \mathrm{C}$. Afterwards, the extract was filtered at vacuum through Whatman grade 2-filter paper and transferred to $10 \mathrm{~mL}$ of petroleum ether. The oil phase was extensively washed with distilled water to remove the residue of acetone, while the residual water was removed by shaking with anhydrous sodium sulphate. A $1 \mathrm{~mL}$ aliquot was used to determine the content of carotenoids using the molar extinction coefficient for $\beta$-carotene in hexane at $450 \mathrm{~nm}$. The extracts were stored in darkness at $-20^{\circ} \mathrm{C}[20]$.

2.4. Chromatographic Profile of Carotenoids. The extracts of carotenoids were reconstituted in $500 \mu \mathrm{L}$ of HPLCgrade ethyl acetate and filtered through nylon membranes $(0.45 \mu \mathrm{m}$, pore size) and then introduced into the C18 column $(25 \mathrm{~cm} \times 4.6 \mathrm{~mm} ; 5 \mu \mathrm{m})$ of the HPLC equipment (Perkin Elmer Binary LC pump 250; series 200, UV/vis Detector). An isocratic elution system was established with acetonitrile-methanol-ethyl acetate $(73: 20: 7)$ working at $0.6 \mathrm{~mL} / \mathrm{min}$ for $70 \mathrm{~min}$, and the absorbance was measured at $450 \mathrm{~nm}[21]$.

2.5. Determination of Free Phenolics. A total of $2 \mathrm{~g}$ of pulp and peel chilli peppers were mixed with $8 \mathrm{~mL}$ of $80 \%$ ethanol, and shaken for $10 \mathrm{~min}$ at $200 \mathrm{rpm}$. The mixture was centrifuged at $13000 \mathrm{rpm}$ at $4^{\circ} \mathrm{C}$ for $10 \mathrm{~min}$. The supernatant was separated by decantation and placed into an amber glass bottle. The sediment was reconstituted into $8 \mathrm{~mL}$ of $80 \%$ ethanol, and the procedure was repeated. Thereby, three extractions were obtained, joined, and stored under a nitrogen atmosphere until analysis [22].

Volumes of $0.75 \mathrm{~mL}$ of Folin-Ciocalteau reagent $(1: 10)$ were added to $100 \mu \mathrm{L}$ of the extract of free phenolics, and the mixture was left to stand for $5 \mathrm{~min}$ in the dark. Afterwards, $0.75 \mathrm{~mL}$ of $\mathrm{NaHCO}_{3} 60 \mathrm{~g} / \mathrm{L}$ solution was added to neutralize the reaction. The solution was left to stand for $90 \mathrm{~min}$, and the absorbance was determined at $725 \mathrm{~nm}$. The result was considered as ferulic acid equivalents [23].

2.6. Chromatographic Profile of Phenolics. Aliquots of $50 \mu \mathrm{L}$ of extract were injected in the HPLC equipment (Perkin 
TABLe 1: Samples.

\begin{tabular}{|c|c|c|c|c|c|}
\hline Species & Variety & Region of origin & $\begin{array}{c}\text { Average annual } \\
\text { temperature }\end{array}$ & Altitude $(\text { masl })^{1}$ & Latitude \\
\hline \multirow[t]{8}{*}{ C. аппиит $\mathrm{L}$} & $\begin{array}{l}\text { Jalapeño } \\
\text { Serrano }\end{array}$ & North: & & & \\
\hline & & Tamaulipas & $24^{\circ} \mathrm{C}$ & 3280 & $27^{\circ} 40^{\prime}-22^{\circ} 12^{\prime}$ \\
\hline & & Sinaloa & $24-36^{\circ} \mathrm{C}$ & 2520 & $27^{\circ} 02^{\prime}-22^{\circ} 29^{\prime}$ \\
\hline & & Jalisco & $18-22^{\circ} \mathrm{C}$ & 4260 & $22^{\circ} 45^{\prime}-18^{\circ} 55^{\prime}$ \\
\hline & $\begin{array}{l}\text { Jalapeño } \\
\text { Serrano }\end{array}$ & Centre: & & & \\
\hline & & Puebla & $22-24^{\circ} \mathrm{C}$ & 5610 & $20^{\circ} 50^{\prime}-17^{\circ} 52^{\prime}$ \\
\hline & & Veracruz 1 & $24-26^{\circ} \mathrm{C}$ & 10 & $19^{\circ} 12^{\prime}$ \\
\hline & & Tlaxcala & $12-14^{\circ} \mathrm{C}$ & 4420 & $19^{\circ} 44^{\prime}-19^{\circ} 06^{\prime}$ \\
\hline \multirow{2}{*}{ C. chinense Jacq. } & Habanero & North: & & & \\
\hline & & Tamaulipas & $24^{\circ} \mathrm{C}$ & 3280 & $27^{\circ} 40^{\prime}-22^{\circ} 12^{\prime}$ \\
\hline
\end{tabular}

${ }^{1}$ Meters above sea level.

Elmer Binary LC pump 250; series 200, UV/vis Detector) using a C18 column $(25 \mathrm{~cm} \times 4.6 \mathrm{~mm} ; 5 \mu \mathrm{m})$. The mobile phase used was a binary system composed of $0.1 \%$ trifluoroacetic acid (Phase A) and 100\% acetonitrile (Phase B). The absorbance was determined at $280 \mathrm{~nm}$. A linear gradient elution was performed at $1 \mathrm{~mL} / \mathrm{min}$. Starting with $90 \%$ phase $\mathrm{A}$ and $10 \%$ phase $\mathrm{B}$, the mixture was eluted to $55 \%$ phase A, $45 \%$ phase B in $50 \mathrm{~min}$ and to $60 \%$ phase $\mathrm{A}$ and $40 \%$ phase $B$ in the last $10 \mathrm{~min}$. Each compound was quantified by comparison with a calibration curve of the corresponding standard [24].

2.7. Statistical Analysis. Analyses of variance (ANOVA) were performed along with Student-Newman-Keuls test for differences between means, using SigmaStat 3.5 software. Principal component analysis (PCA) of the FTIR extract spectra was performed by using the OPUS QUANT (version 6.5) and Minitab (version 14) software.

2.8. Analysis by Infrared Spectroscopy. The dry extracts were reconstituted in petroleum ether, for carotenoids, and in ethanol, for phenolics, in order to obtain a semisolid consistency of the sample. Afterwards, the mixtures were analyzed in a FT (Fourier transform)-infrared spectrometer (Bruker Vertex 70), by using the ATR (attenuated total reflectance) sampling method previously described [25]. Briefly, a small sample amount is placed over a ZnSe crystal, where the infrared radiation is propagated and interacts with the sample to obtain the corresponding spectrum, which is averaged from several data acquisitions.

2.9. DNA Extraction. The method described by Allers and Lichten [26] was used for DNA extraction, after modifications. All samples of chilli peppers were washed with water, disinfected with sodium hypochlorite at 10\%, 30\%, and $70 \%$ ethanol, exhaustively rinsed with distilled water for $20 \mathrm{~min}$ and stored at $-70^{\circ} \mathrm{C}$, under sterile conditions. The pulp and peel of chilli peppers were crushed in mortars using liquid nitrogen. Portions of $100 \mathrm{mg}$ per sample were mixed with $400 \mu \mathrm{L}$ of lysis buffer $(200 \mathrm{mM}$ Tris- $\mathrm{HCl} \mathrm{pH}$ 6.5, $70 \mathrm{mM}$ EDTA pH 8, $2 \mathrm{mM} \mathrm{NaCl}, 2 \%$ PVP 40, $20 \mathrm{mM}$ sodium metabisulphite, $1 \%$ Triton X-100, $24 \mathrm{mM} \mathrm{MgCl}_{2} / \mathrm{MgSO}_{4}$, $0.1 \%$ spermine, and $0.1 \%$ spermidine) previously heated at $60^{\circ} \mathrm{C}$. The mixture was agitated and incubated at $60^{\circ} \mathrm{C}$ for $60 \mathrm{~min}$; then it was transferred to ice, at which time $400 \mu \mathrm{L}$ of $10 \%$ PVP was added. The mixture was agitated by inversion of the recipient and left to stand for $60 \mathrm{~min}$ at $-20^{\circ} \mathrm{C}$. Afterwards, the blend was centrifuged at $4000 \mathrm{rpm}$ for $30 \mathrm{~min}$, and $400 \mu \mathrm{L}$ of each supernatant was transferred into new tubes, in order to add $5 \mu \mathrm{L}$ of $10 \mathrm{mg} / \mathrm{mL}$ RNasa for $10 \mathrm{~min}$ at room temperature. Immediately, the supernatants were precipitated by addition of $200 \mu \mathrm{L}$ of $10 \mathrm{M}$ ammonium acetate and $600 \mu \mathrm{L}$ of cold isopropanol. The mixture was agitated by inversion of the tube and incubated overnight at $-20^{\circ} \mathrm{C}$. The mixture was then centrifuged at $4000 \mathrm{rpm}$ for $30 \mathrm{~min}$ at $10^{\circ} \mathrm{C}$, the isopropanol eliminated, and the pellet washed with $1 \mathrm{~mL}$ of cold $70 \%$ ethanol, followed by centrifugation for $10 \mathrm{~min}$ under the same operation conditions. Finally, the ethanol was removed, and the pellet was dried for $20 \mathrm{~min}$ at room temperature.

The pellets were reconstituted into $200 \mu \mathrm{L}$ of $10 \mathrm{mM}$ Tris $\mathrm{pH} 8$, and the DNA was precipitated again with $200 \mu \mathrm{L}$ of PEG $800030 \%-\mathrm{NaCl} 1.2 \mathrm{M}$ at $4^{\circ} \mathrm{C}$ for $60 \mathrm{~min}$. The mixture was then centrifuged for $30 \mathrm{~min}$ at $4000 \mathrm{rpm}$ and $10^{\circ} \mathrm{C}$. The supernatants from PEG were discarded, and the DNA pellet was washed with $1.5 \mathrm{~mL}$ of cold $70 \%$ ethanol, followed by centrifugation for $15 \mathrm{~min}$ at $4000 \mathrm{rpm}$. The ethanol was eliminated and the DNA pellet left to dry, and finally reconstituted into $200 \mu \mathrm{L}$ of $10 \mathrm{mM}$ Tris $\mathrm{pH} 8$ [26].

The purity of the extracted DNA was determined by absorbance at 260/280 ratio, and values greater than 1.8 were accepted for future procedures. The DNA was quantified by its absorbance at $260 \mathrm{~nm}$ [27].

2.10. RAPD. For DNA amplification, a thermocycler (Bioer $\mathrm{XP}$ cycler) was used under the following operation settings: 1 cycle of $5 \mathrm{~min}$ at $94^{\circ} \mathrm{C} ; 40$ cycles of $1 \mathrm{~min}$ at 
TABLE 2: Size and weight of the Serrano, Jalapeño, and Habanero chilli pepper varieties.

\begin{tabular}{|c|c|c|c|c|}
\hline Sample & Origin & Weight (g) & Length $(\mathrm{cm})$ & Width $(\mathrm{cm})$ \\
\hline \multirow{7}{*}{ Jalapeño } & Tamaulipas & $46.5 \pm 4.1^{\mathrm{a}}$ & $8.6 \pm 0.8^{\mathrm{a}}$ & $3.4 \pm 0.2^{\mathrm{a}}$ \\
\hline & Sinaloa & $25.9 \pm 3.6^{\mathrm{a}}$ & $7.3 \pm 0.6^{\mathrm{a}}$ & $2.8 \pm 0.2^{\mathrm{a}}$ \\
\hline & Jalisco & $33.7 \pm 6.1^{\mathrm{a}}$ & $7.5 \pm 0.8^{\mathrm{a}}$ & $3.2 \pm 0.3^{\mathrm{a}}$ \\
\hline & Puebla & $25.9 \pm 4.2^{\mathrm{a}}$ & $7.1 \pm 1.0^{\mathrm{a}}$ & $3.0 \pm 0.3^{\mathrm{a}}$ \\
\hline & Veracruz 1 & $31.8 \pm 5.5^{\mathrm{a}}$ & $7.6 \pm 0.8^{\mathrm{a}}$ & $3.0 \pm 0.2^{\mathrm{a}}$ \\
\hline & Veracruz 2 & $45.9 \pm 3.6^{\mathrm{a}}$ & $9.5 \pm 0.6^{\mathrm{a}}$ & $3.3 \pm 0.4^{\mathrm{a}}$ \\
\hline & Tlaxcala & $33.7 \pm 3.2^{\mathrm{a}}$ & $8.9 \pm 0.6^{\mathrm{a}}$ & $2.9 \pm 0.2^{\mathrm{a}}$ \\
\hline \multirow{7}{*}{ Serrano } & Tamaulipas & $11.2 \pm 2.5^{\mathrm{b}}$ & $6.7 \pm 0.8^{\mathrm{a}}$ & $1.7 \pm 0.2^{b}$ \\
\hline & Sinaloa & $12.8 \pm 2.8^{\mathrm{b}}$ & $7.3 \pm 0.8^{\mathrm{a}}$ & $1.9 \pm 0.2^{b}$ \\
\hline & Jalisco & $16.4 \pm 2.5^{\mathrm{b}}$ & $9.0 \pm 0.9^{\mathrm{a}}$ & $1.9 \pm 0.1^{b}$ \\
\hline & Puebla & $3.8 \pm 1.3^{\mathrm{b}}$ & $7.6 \pm 0.9^{\mathrm{a}}$ & $0.1 \pm 0.01^{\mathrm{b}}$ \\
\hline & Veracruz 1 & $3.0 \pm 0.9^{\mathrm{b}}$ & $6.7 \pm 0.5^{\mathrm{a}}$ & $0.9 \pm 0.08^{\mathrm{b}}$ \\
\hline & Veracruz 2 & $9.6 \pm 2.2^{\mathrm{b}}$ & $7.4 \pm 0.3^{\mathrm{a}}$ & $1.5 \pm 0.1^{b}$ \\
\hline & Tlaxcala & $3.3 \pm 0.9^{\mathrm{b}}$ & $6.5 \pm 0.4^{\mathrm{a}}$ & $0.8 \pm 0.1^{\mathrm{b}}$ \\
\hline Habanero & Tamaulipas & $8.1 \pm 1.3^{c}$ & $4.3 \pm 0.4^{\mathrm{b}}$ & $2.6 \pm 0.3^{c}$ \\
\hline
\end{tabular}

Values correspond to measurements carried on different chilli pepper units. Different letters in the same row mean, $P \leq 0.05$.

TABLE 3: Content of carotenoids in chilli samples.

\begin{tabular}{lcc}
\hline Sample & \multicolumn{2}{c}{ Carotenoid content } \\
& Fresh & Mature \\
\hline J T & n. a. ${ }^{2}$ & $3.059 \pm 0.17^{\mathrm{ab}}$ \\
J Si & $0.359 \pm 0.32^{\mathrm{ac}}$ & $2.0917 \pm 0.72^{\mathrm{ac}}$ \\
J P & $0.998 \pm 0.13^{\mathrm{ad}}$ & $2.488 \pm 0.06^{\mathrm{ab}}$ \\
J V1 & $0.128 \pm 0.02^{\mathrm{ac}}$ & $2.682 \pm 0.31^{\mathrm{ab}}$ \\
J V2 & $0.161 \pm 0.004^{\mathrm{ac}}$ & $0.711 \pm 0^{\mathrm{ab}}$ \\
J Tx & $0.943 \pm 0.03^{\mathrm{ad}}$ & $1.317 \pm 0.2612^{\mathrm{a}}$ \\
S T & n. a. & $0.696 \pm 0.16^{\mathrm{ab}}$ \\
S Si & $0.083 \pm 0.01^{\mathrm{be}}$ & $13.850 \pm 3.11^{\mathrm{ac}}$ \\
S Jc & $0.935 \pm 0.14^{\mathrm{be}}$ & $5.690 \pm 0.11^{\mathrm{ab}}$ \\
S P & $0.520 \pm 0.07^{\mathrm{bf}}$ & $0.792 \pm 0.25^{\mathrm{ac}}$ \\
S Tx & $0.889 \pm 0.26^{\mathrm{bf}}$ & $6.444 \pm 1.09^{\mathrm{a}}$ \\
H T & n. a. & $0.730 \pm 0.27^{\mathrm{a}}$ \\
\hline
\end{tabular}

Jalapeño (J); Serrano (S); Habanero (H); Tamaulipas (T); Sinaloa (Si); Jalisco (Jc); Puebla (P); Veracruz (V); Tlaxcala (Tx).

Different letters in the same row mean indicar valor $P=0.05$.

${ }^{1}$ dry basis.

${ }^{2}$ not available.

$94^{\circ} \mathrm{C}$; $1 \mathrm{~min}$ at $36^{\circ} \mathrm{C}, 2 \mathrm{~min}$ at $72^{\circ} \mathrm{C}$; a final extension step of $10 \mathrm{~min}$ at $72^{\circ} \mathrm{C}$. PCR reactions were performed in a volume of $25 \mu \mathrm{L}$ containing $1 \mathrm{X}$ PCR buffer, $50 \mathrm{nM}$ of $\mathrm{MgCl}_{2}, 200 \mu \mathrm{M}$ dNTP, 1.5 units of the enzyme Taq DNA polymerase (Invitrogen, Brazil), and $40-100 \mathrm{ng} / \mu \mathrm{L}$ DNA samples [27]. Four independent reactions were assayed using $0.4 \mu \mathrm{M}$ oligonucleotide OPE18 (CGGCCCACGT), or
$0.2 \mu \mathrm{M}$ oligonucleotide MFG17 (CGCGTTCTTG), $0.2 \mu \mathrm{M}$ oligonucleotide MFG18 (CGGCCCACGT), or $0.2 \mu \mathrm{M}$ C51 (ATCAACGTACGT) and $0.2 \mu \mathrm{M}$ C52 (GTCGACGGACGT) oligonucleotide mixture (Invitrogen) $[4,28]$.

The products of DNA amplification were analyzed by electrophoresis in 1.5\% agarose gel, using TAE $1 \mathrm{x}$ buffer. The gels were stained with ethidium bromide $(0.2 \mu \mathrm{L} / \mathrm{mL})$ and observed with an UV-transilluminator (Stratagene Eagle Eye).

In order to increase reproducibility, optimum conditions were established for DNA extraction and amplification, without modifying $\mathrm{Mg} 2+$ concentration, for Taq polymerase enzyme and primers as well as for the DNA concentration in each reaction.

2.11. Data Matrix and Dendrogram. The polymorphic bands and signals of the chromatograms were considered as "present" or "absent" in a matrix of similarity. For the chromatogram, only signals above 40 milli-units of absorbance were considered "present." The method of average grouping UPGMA was used and determined by means of the analysis Cluster by using the software Paleontological Statistics (PAST) 2.10, taking into account the Dice's similarity coefficient and the Euclidean distance.

\section{Results and Discussion}

3.1. Size and Weight. The weight of the different varieties of chilli peppers ranged from 3 to $46 \mathrm{~g}$. In general, samples with the best morphological characteristics (color, size, texture, and weight) were those from the northern region, except for the sample JV1 from the south-central area, the latter being the lighter weight. The length was from 4.3 to $9.5 \mathrm{~cm}$, 
TABLE 4: Concentration intervals of different carotenoids in different chilli varieties.

\begin{tabular}{|c|c|c|c|c|}
\hline \multirow{2}{*}{ Sample } & \multicolumn{4}{|c|}{ Carotenoid content $\left(\mu \mathrm{g} / \mathrm{g} \mathrm{DB}^{1}\right)$} \\
\hline & Lutein & Lycopene & $\beta$-cryptoxanthin & $\beta$-carotene \\
\hline \multicolumn{5}{|l|}{ Jalapeño } \\
\hline fresh & $243.4-512.1$ & $259.9-512.1$ & $42.8-47.1$ & $188.6-394.7$ \\
\hline mature & $157.9-868.4$ & $157.9-868.4$ & $37.8-115.1$ & $8.2-496.6$ \\
\hline \multicolumn{5}{|l|}{ Serrano } \\
\hline fresh & $102.6-728.9$ & $102.6-728.9$ & $7.1-164.5$ & $62.5-523.0$ \\
\hline mature & $77.8-486.3$ & $199.6-486.3$ & $44.0-70.1$ & $76.0-485.3$ \\
\hline \multicolumn{5}{|l|}{ Habaneros } \\
\hline mature & 37.5 & 37.5 & 55.9 & 62.7 \\
\hline
\end{tabular}

${ }^{1}$ Dry basis. Average obtained by triplicate.

TABLE 5: Total content of phenolic compounds in the chilli varieties under study.

\begin{tabular}{lcc}
\hline Sample & \multicolumn{2}{c}{ Equivalents of ferulic acid $\left(\mu \mathrm{g} / \mathrm{g} \mathrm{DB}^{1}\right)$} \\
& Fresh & Mature \\
\hline JT & n. a. ${ }^{2}$ & $38.6 \pm 0.9^{\mathrm{a}}$ \\
JSi & $128.4 \pm 1.1^{\mathrm{ac}}$ & $67.5 \pm 5.9^{\mathrm{a}}$ \\
JJco & $121.4 \pm 15.6^{\mathrm{ac}}$ & $61.4 \pm 0.0^{\mathrm{a}}$ \\
JP & $44.4 \pm 2.1^{\mathrm{ad}}$ & $94.0 \pm 4.0^{\mathrm{a}}$ \\
JV1 & $37.0 \pm 0.7^{\mathrm{ad}}$ & $72.8 \pm 1.1^{\mathrm{a}}$ \\
JV2 & $30.2 \pm 1.3^{\mathrm{ad}}$ & $66.8 \pm 2.1^{\mathrm{a}}$ \\
JTx & $62.8 \pm 2.2^{\mathrm{a}}$ & $72.1 \pm 0.8^{\mathrm{a}}$ \\
ST & n. a. & $108.0 \pm 19.2^{\mathrm{b}}$ \\
SSi & $55.7 \pm 1.2^{\mathrm{b}}$ & $67.3 \pm 2.7^{\mathrm{b}}$ \\
SJc & $42.1 \pm 5.2^{\mathrm{be}}$ & $297.8 \pm 26.2^{\mathrm{b}}$ \\
SP & $60.3 \pm 0.8^{\mathrm{bf}}$ & $167 \pm 48.9^{\mathrm{b}}$ \\
SV1 & $48.8 \pm 7.4^{\mathrm{b}}$ & $79.9 \pm 8.1^{\mathrm{b}}$ \\
SV2 & $43.1 \pm 5.4^{\mathrm{bd}}$ & $60.8 \pm 2.1^{\mathrm{b}}$ \\
STx & $63.6 \pm 3.2^{\mathrm{bf}}$ & $83.2 \pm 3.5^{\mathrm{b}}$ \\
HT & n. a. & $89.5 \pm 1.5^{\mathrm{ab}}$ \\
\hline
\end{tabular}

Jalapeño (J); Serrano (S); Habanero (H); Tamaulipas (T); Sinaloa (Si); Jalisco (Jc); Puebla (P); Veracruz (V); Tlaxcala (Tx).

Different letters in the same row mean statistically significant difference.

1 dry basis;

2 not available.

and the width was in the range of 0.1 to $3.34 \mathrm{~cm}$. The three varieties of chilli showed differences in both weight and size, with remarkable greater similarities between the same species (Jalapeño and Serrano) as well as those grown in nearby areas. For instance, the Serrano chilli peppers grown in $\mathrm{Tx}, \mathrm{P}$, and $\mathrm{V} 1$ from the central region were quite similar. Through statistical analysis, significant differences were found in weight and width between varieties, but not in length between Serrano and Jalapeño (i.e., the same species). However, these two peppers showed significant difference with respect to Habanero (i.e., a different species) (see Table 2).

3.2. Total Content of Carotenoids. The content of carotenoids in fresh peppers varied within the interval $0.083-0.99 \mathrm{mg} / \mathrm{g}$ dry basis (DB), while mature peppers were in the range from 0.69 to $13.85 \mathrm{mg} / \mathrm{g} \mathrm{DB}$. The carotenoid content increased from the fresh to the mature state, as expected accordingly to the natural biosynthesis of pigments as the fruit matures [29]. In accordance with the statistical analysis, of chilli peppers in the fresh stage, there were significant differences between Jalapeño and Serrano varieties, while analysis of mature peppers, showed no differences between the three cultivars (see Table 3). This is due to the ability of fruits to synthesize carotenoids during the ripening process regardless of the species [30]. Regarding the region, fresh Jalapeño peppers from $\mathrm{Tx}$ and $\mathrm{P}$ were found to be different than those from $V$ and S, while fresh Serrano peppers showed statistical difference in all cases except those from Jc and those from Si. Mature chilli peppers, from Si showed differences with respect to those from T, P, V1 and V2. Therefore, no association was found between the concentration of carotenoids and the geographical origin.

The results presented above could be affected also by the environmental conditions, such as temperature and relative humidity, as well as the type of soil, which of course are related to the proximity of the different geographical regions.

3.3. Identification and Quantification of Carotenoids. Among the identified carotenoids were lutein, $\beta$-cryptoxanthin, lycopene, and $\beta$-carotene, with a higher concentration of lutein and lycopene. The latter are part of the main carotenoids present in chilli $[29,31]$. During the process of maturation, Lutein remained constant for Jalapeño peppers, whereas it diminished for Serrano ones. However, it has been reported that lutein disappears in mature peppers by the effect of the synthesis of pigments in chromoplasts [32]. Similarly, many of the hydroxylated carotenoids are progressively esterified with fatty acids [33]. Lycopene also 
TABLE 6: Content of phenolic compounds in chilli samples.

\begin{tabular}{|c|c|c|c|c|c|c|}
\hline \multirow{2}{*}{ Sample } & \multicolumn{6}{|c|}{ Content of phenolic compounds $\left(\mathrm{M}^{*}\right)$} \\
\hline & Gallic acid & Protocatechuic acid & Ferulic acid & $\begin{array}{c}o \text {-coumaric } \\
\text { acid }\end{array}$ & $\begin{array}{c}p \text {-coumaric } \\
\text { acid }\end{array}$ & $\begin{array}{c}\text { Sinapinic } \\
\text { acid }\end{array}$ \\
\hline \multicolumn{7}{|l|}{ Jalapeño } \\
\hline fresh & $0.15-0.18$ & $0.06-0.33$ & $0.31-0.81$ & $0.58-3.05$ & $0.05-0.42$ & $0.14-0.78$ \\
\hline mature & $\begin{array}{c}35.8- \\
2783.2\end{array}$ & $0.40-1.36$ & $0.10-1.13$ & $0.80-5.40$ & $1.82-6.93$ & $0.07-0.64$ \\
\hline \multicolumn{7}{|l|}{ Serrano } \\
\hline fresh & $1.84-9.27$ & $0.10-0.18$ & $0.04-0.47$ & $0.54-2.77$ & $0.04-0.57$ & $0.07-0.55$ \\
\hline mature & $0.36-8.68$ & $0.10-1.21$ & $0.019-0.47$ & $0.67-2.22$ & $0.59-4.13$ & $0.05-0.79$ \\
\hline \multicolumn{7}{|l|}{ Habanero } \\
\hline \multirow[t]{2}{*}{ mature } & 0.98 & 0.004 & 0.13 & 0.71 & 0.25 & 8.55 \\
\hline & $\begin{array}{l}\text { t-cinnamic } \\
\text { acid }\end{array}$ & Caffeic acid & Quercetin & Catechin & Rutin & Vanillin \\
\hline \multicolumn{7}{|l|}{$\begin{array}{l}\text { Jalapeño } \\
\end{array}$} \\
\hline fresh & $0.12-0.68$ & $0.09-0.42$ & $0.15-0.18$ & $3.72-22.1$ & $0.01-0.16$ & $0.03-0.36$ \\
\hline mature & $0.09-1.53$ & $0.08-0.41$ & $0.23-1.35$ & $5.8-7.96$ & $0.31-0.74$ & $0.03-2.84$ \\
\hline \multicolumn{7}{|l|}{ Serrano } \\
\hline fresh & $0.02-0.35$ & $0.04-1.22$ & $0.10-0.28$ & $0.84-7.35$ & $0.04-0.31$ & $0.13-0.83$ \\
\hline mature & $0.16-0.76$ & $0.03-1.30$ & $0.10-1.08$ & $1.79-15.85$ & $0.03-0.77$ & $0.20-0.57$ \\
\hline \multicolumn{7}{|l|}{ Habanero } \\
\hline mature & 1.25 & 0.55 & 0.15 & 1.80 & 0.03 & 0.65 \\
\hline
\end{tabular}

tends to decrease as maturation proceeds. Contrarily $\beta$ cryptoxanthin and the $\beta$-carotene increase during the ripening process, as reported by Marín et al. [29].

According to statistical analysis, no significant differences were found for fresh peppers in concentrations of lutein, lycopene, and $\beta$-cryptoxanthin between Jalapeño and Serrano cultivars. Nonetheless, there were differences in $\beta$ carotene content, which is the major compound in several varieties of C. annuum L. [30]. On the other hand, differences were found for mature peppers only between Jalapeño and Serrano, in this case in lutein and lycopene content (Table 4).

3.4. Total Content of Phenolics. The concentration of phenolic compounds in fresh peppers ranged from 30.2 to $128.4 \mathrm{mg} / \mathrm{g}$, whereas in the mature peppers it ranged from 38.6 to $297.8 \mu \mathrm{g} / \mu \mathrm{L}$ on dry weight basis. In most of the samples, there was a noteworthy increase in these compounds in mature chilli peppers, in agreement with the results of Deepa et al. [32]. However, other studies, such as those by Oboh et al. [5] and Zhang and Hamauzu [31] show that the content of phenolic compounds are significantly higher in the fresh peppers than in the mature ones. Given the above, the main factors involved in the variation of phenolic content are the maturation state, as well as the age of the plant, as reported by Deepa et al. [32].

When doing a comparison on the total phenolic content within the chilli varieties, significant differences were found between Serrano and Jalapeño, for both fresh and mature stages, while between Jalapeño and Serrano as a group no differences were detected with respect to Habanero. These results are inconsistent with data reported by Oboh et al. [5], where the phenolics content was significantly higher for the C. annuum $\mathrm{L}$. than for the $C$. chinense Jacq species.

Concerning the region, differences were found in most of fresh Jalapeño peppers samples, except between $\mathrm{P}$ and $\mathrm{V}$ (V1 and V2) and between Si and Jco. For the fresh Serrano peppers, there were differences between $\mathrm{Tx}$ and $\mathrm{P}$ with respect to Jc and V2. For mature peppers, the region seems to be unimportant (see Table 5). From these results, certain patterns indicate differences between varieties and other between cultivars, in agreement with Antonious et al. [34] who reported significant differences between cultivars of C. baccatum L. and C. chinense Jacq, and between two genotypes of the latter variety.

3.5. Identification and Quantification of Phenolic Compounds by HPLC. The phenolic compounds found in chilli peppers were gallic, protocatechuic, ferulic, $o$-coumaric, $p$-coumaric, sinapinic, trans-cinnamic and caffeic acids, quercetin, catechin, rutin, and vanillin. Many of these compounds belong to the pathway of phenylpropanoids which is characteristic of chilli species.

Among the varieties of chilli, significant differences were found between Serrano and Jalapeño in the gallic and $p$ coumaric acids content, indifferently of maturation stage. Regarding protocatechuic and caffeic acids as well as catechin and vanillin, there were differences only for fresh peppers. For the mature stage, the only difference was found in the 


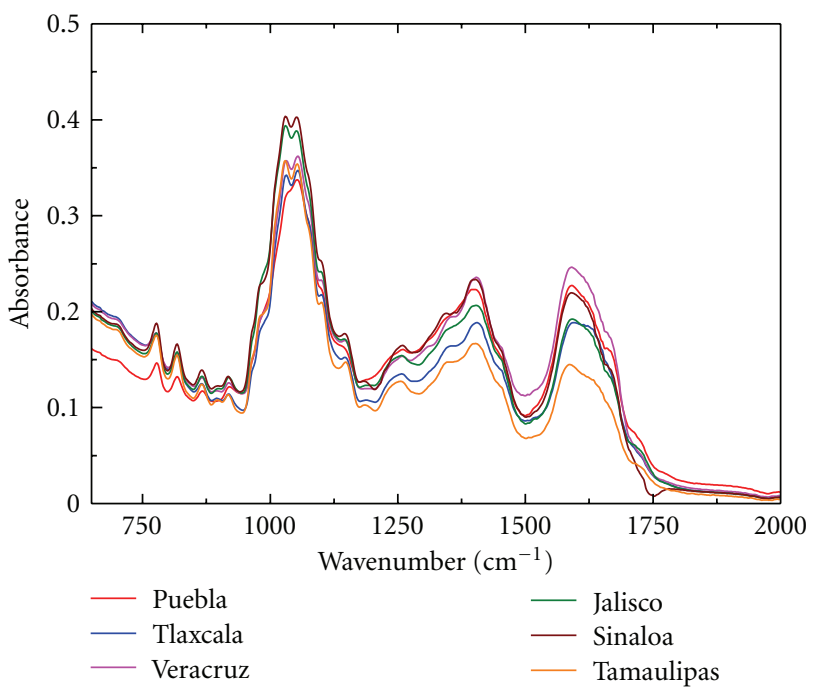

FIGURE 1: FTIR spectra of phenolic compounds in chilli samples.

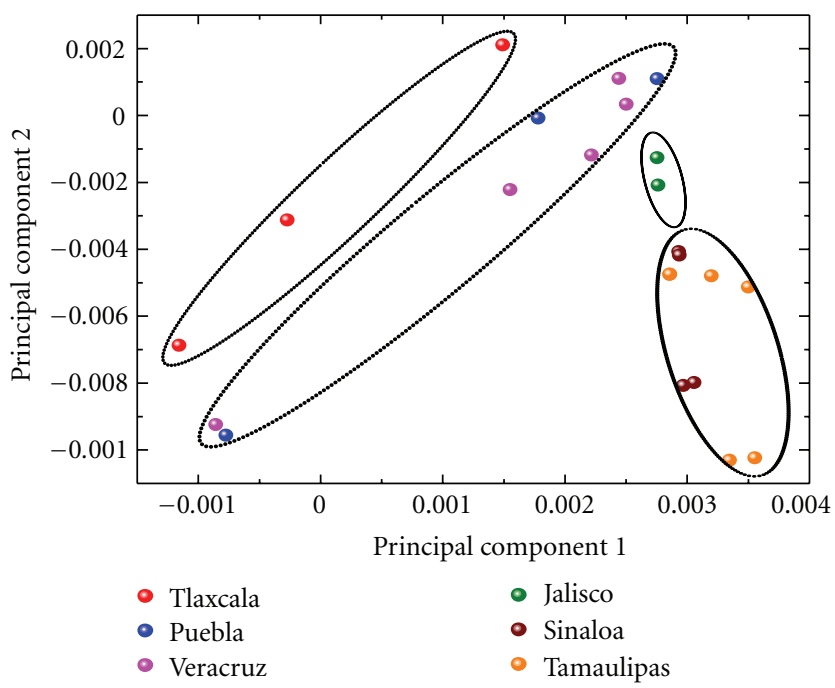

FIGURE 2: PCA for phenolic compounds in chilli samples grouped by region.

content of trans-cinnamic acid between the two varieties (Table 6).

Regarding the place of origin, fresh Jalapeño peppers showed differences in the content of sinapic acid between $\mathrm{Si}$ samples and the rest, in the content of catechin of $\mathrm{V}$ samples compared to $\mathrm{P}$ and Tx samples (despite the fact that all three belong to the central region), and in the content of $p$ coumaric acid of $\mathrm{P}$ compared to V1, Tx, and Si. The fresh Serrano peppers showed differences in the concentration of gallic acid for samples from $\mathrm{Si}$ with respect to $\mathrm{P}$ and $\mathrm{V}$. In the content of protocatechuic acid for samples from $\mathrm{P}$ with respect to the other specimens, and in the content of caffeic acid and rutin for V2 with respect to the other specimens. Finally, most regions showed differences in the content of p-coumaric acid, except for V2 compared to $\mathrm{P}$ and S, V1

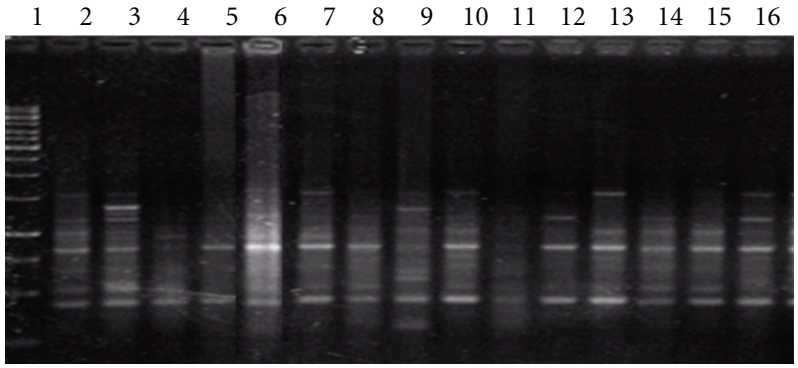

(a)

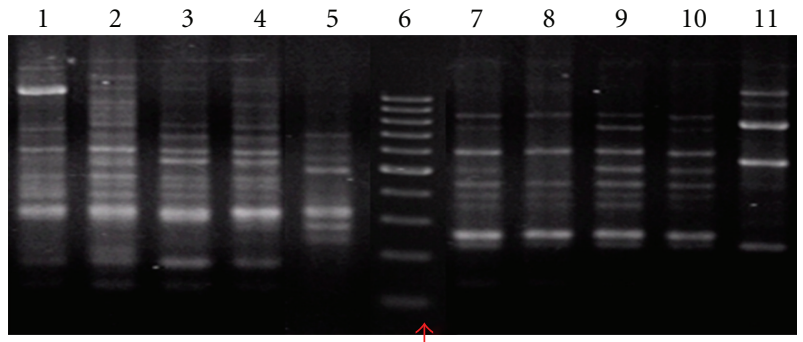

(b)

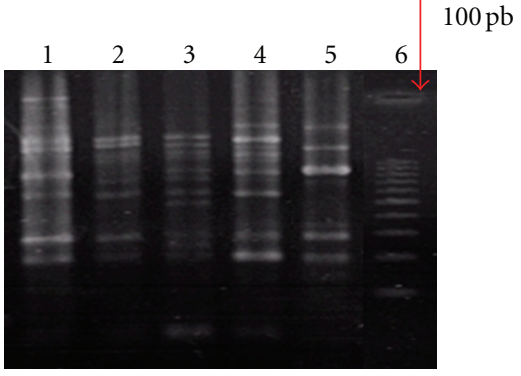

(c)

Figure 3: RAPD profiles of Serrano, Jalapeño, and Habanero chilli peppers. (a) oligonucleotide OPE-18. 1: 1000 bp DNA ladder; 2: JT; 3: JSi; 4: JJ; 5: JP; 6: JV1; 7: JV2; 8: JTx; 9: HT; 10: ST; 11: SSi; 12: SJco; 13: SP; 14: SV1; 15: SV2; 16: STx. (b) oligonucleotides MAF-17 (right) and MFG-18 (left): 1 and 7, JSi; 2 and 8, JV1; 3 and 9, STx; 4 and 10, ST; 5 and 11, HT; 6, 100 bp DNA ladder. (c): oligonucleotides C51 and C52 mix: 1, JSi; 2, JV1; 3, STx; 4, ST; 5, HT; 6, 100 bp DNA ladder.

compared to Jc and $\mathrm{Tx}, \mathrm{P}$ compared to $\mathrm{Si}$, and Jc compared to $\mathrm{Tx}$, showing no association between geographical areas.

Among mature Jalapeño peppers, T showed differences with respect to $\mathrm{Si}$ in the content of gallic acid and with respect to V1 in protocatechuic acid. No differences were found between the mature Serrano peppers with respect to region.

By taking into account the state of maturation, for the rest of the phenolic compounds, there were not many differences as observed by the maturation stage in the content of gallic, protocatechuic, trans-cinnamic and p-coumaric acids; quercetin, rutin, and vanillin. For the rest of the phenolic compounds, there were no differences that could be explained by the maturation stage.

Within a Jalapeño variety, differences were found between fresh and mature peppers in the content of gallic acid, while no such difference existed in the content of ferulic 


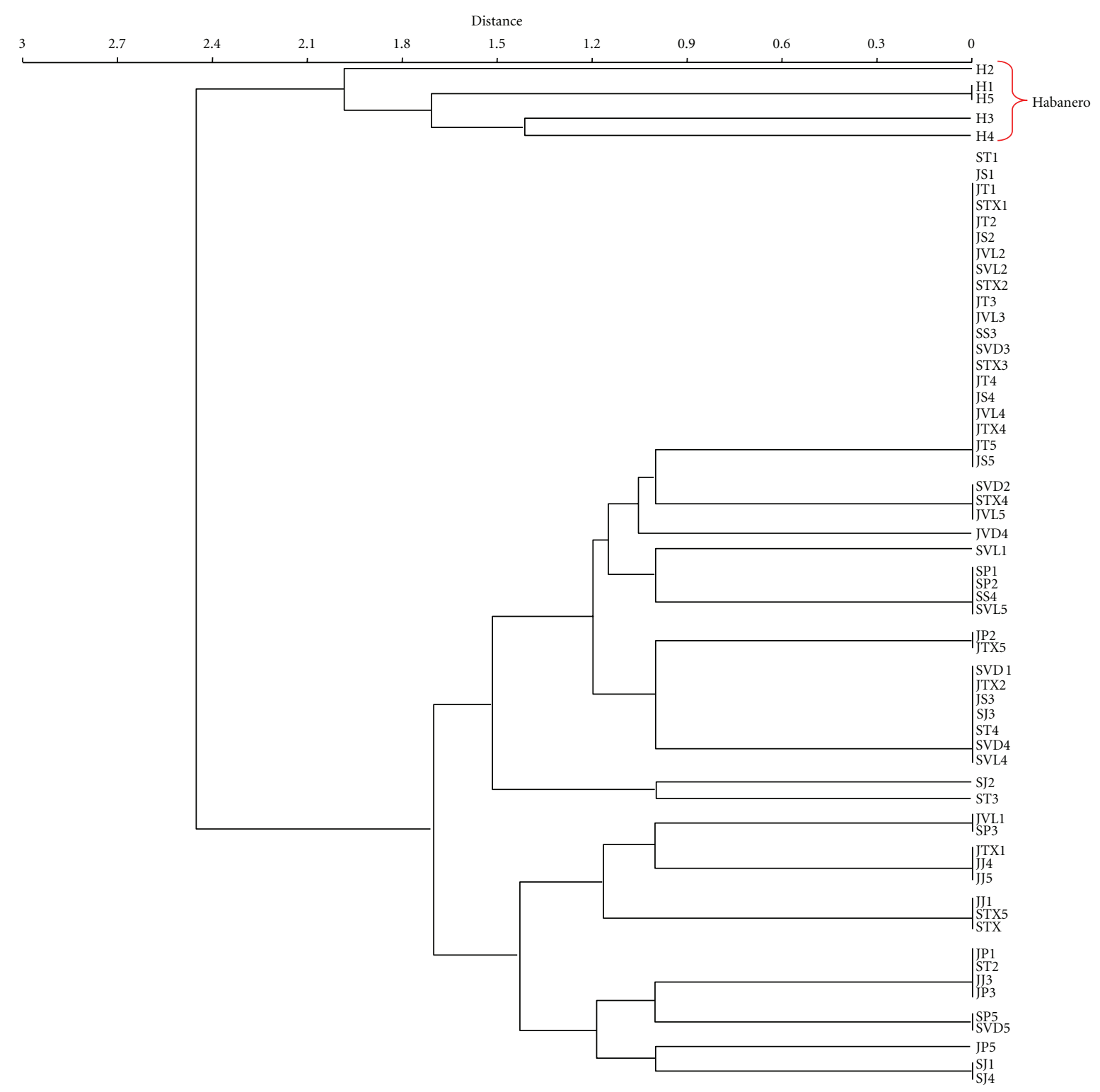

FIgURE 4: Euclidean distance dendrogram of C. annuum L. (Jalapeño and Serrano chilli peppers) and C. chinense Jacq. (Habanero chilli peppers) based in OPE-18 RAPD markers.

acid. For mature specimens no differences were found only between the three varieties in the content of protocatechuic acid, caffeic acid, and catechin, while the fresh samples reported differences in the content of p-coumaric acid, catechin, and vanillin.

It is clear from the results that variations exist between the three variables and concentrations. Some interactions can be explained by the proximity of the geographical areas, as in the case of $\mathrm{P}, \mathrm{Tx}, \mathrm{V}$, and T. Other differences may be due to the growing conditions of each geographic region or by the genotype of the chilli, as discussed earlier by Silva et al. [12]. These authors studied the content of rutin in a medicinal fruit from Brazil and found that the high variability in the concentration and the great genetic variability of the fruit may be associated not only with genetic differences, but also with environmental conditions.
3.6. Analysis of Phenolic Compounds by Infrared Spectroscopy. The typical IR spectra $\left(600-2000 \mathrm{~cm}^{-1}\right)$ of phenolic extracts from different geographical regions of Mexico (Figure 1) do not show a clear difference between samples. However, by applying principal component analysis (PCA) (Figure 2) to the second derivative of the spectra, four clusters were found. In the first cluster samples, $\mathrm{P}$ appeared with a variation axis which is parallel to the association to a second group of Tx and V, that is, with similar chemical characteristics. The third cluster, Si and T samples were able to associate and the fourth group to Jc samples, but perpendicular to the previous samples, so, the latter three were related to each other, but showed differences with the former.

We can say that the associations of geographic location could be due to the environmental conditions, that is the geographical environment determines the concentration 


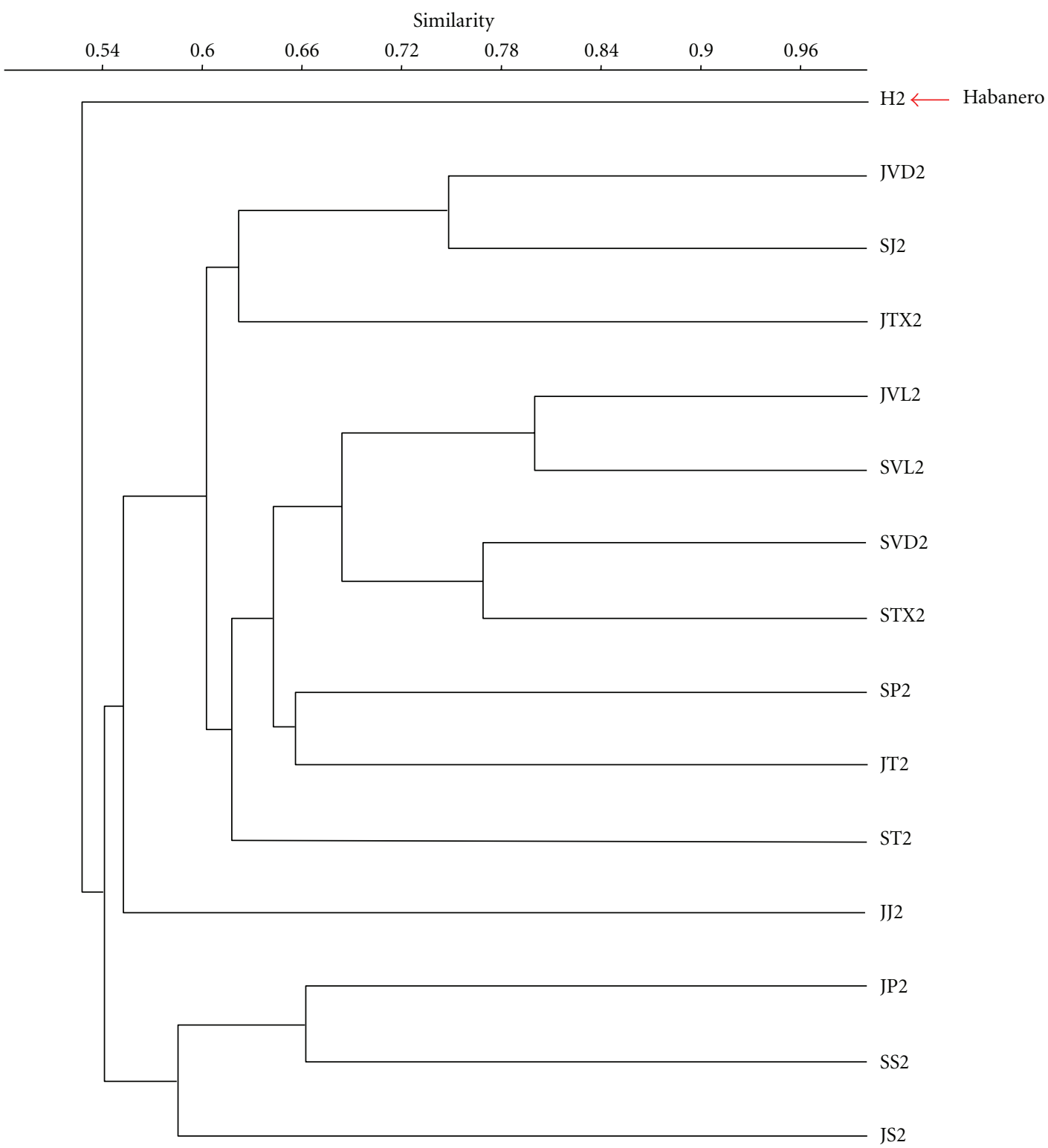

Figure 5: Dendrogram of Jalapeño, Serrano, and Habanero chilli peppers, considering the presence/absence of polymorphic fragments as detected with the method RAPD by using the oligonucleotide OPE-18 and the chromatographic profile of carotenoids in mature peppers.

of compounds in peppers. By joining these results with the total content of phenolics, and by chromatography, the same association for $\mathrm{P}, \mathrm{Tx}$, and $\mathrm{V}$ in concentration of trans-cinnamic, gallic, $p$-coumaric, protocatechuic acids, quercetin, and catechin can be found.

In the present study, it has been found that FTIR spectroscopy combined with the PCA method presents great potential for the verification of the geographic origin of phenolic samples. PCA gives a dimensional matrix. Regarding the principal components that were generated, that was too reduced to perform discrimination. Such discrimination was realized by using the second derivative of the spectra in the region $\left(900-1750 \mathrm{~cm}^{-1}\right)$. These results show that this FTIRPCA analysis could be used as an alternative, quick, and low-cost method for identification of the geographic origin of Mexican chilli peppers (C. annuum L.) through their phenolic compounds.

For variables regarding type and maturation stage, it was not possible to find differences because the geographical variation, influenced by climatic and growing conditions, was more important than these variables.

3.7. RAPD. Among the oligonucleotides tested, OPE- 18 was the most polymorphic RAPD oligonucleotide generating a total 10 bands. From the RAPD reactions carried out with a mixture of MFG-17 and MFG18 oligonucleotides and C51 to C52 oligonucleotides mixture a total of 25 and 17 bands were obtained, respectively. Independently of the oligonucleotide used, Serrano and Jalapeño chilli peppers exhibit similar RAPD profiles, whereas Habanero chilli peppers exhibited 
a particular profile with only 3 or 4 common bands. The majority of the bands were polymorphic, although some monomorphic bands were observed. Some examples of profiles obtained can be observed in Figure 3.

The presence/absence and similitude matrixes derived from the most informative primer (OPE-18) were obtained, and an Euclidean distance dendogram was constructed with 10 polymorphic bands $(r=0.94)$ (Figure 4). C. chinense Jacq. (Habanero chilli peppers) samples were clearly clustered apart from the C. annuum L. (Serrano and Jalapeño chilli peppers), confirming the clear differences (coefficient of 2.0) observed among RAPD profiles. Basically, all samples formed three clusters: the first group made by the habanero peppers and the second and third groups do not show a clear separation between cultivars. A previous RAPD analysis using 10 germplasm samples of C. annuum L from Thailand revealed a higher diversity of RAPD profiles those found in Mexican samples [4]. Moreover, other RAPD diversity analysis of C. annuum variety "Cuneo" from northwest Italy distinguished five populations [35]. Possibly, the limited profile diversity and high similitude observed in two Mexican varieties studied can be explained by selective pressure derived from culture practices and commercial interests. Evidently, RAPD confirmed the great morphological diversity observed among C. annuum $\mathrm{L}$ varieties around the world, but an extensive study is necessary for molecular intraspecific diversity and population genetics including many C. annuum $\mathrm{L}$ varieties collected from different parts of the world.

3.8. Genetic Analysis with Chromatographic Profiles. According to the dendrogram coupled to the amplification by oligonucleotide OPE-18 and the chromatographic profile of carotenoids in mature peppers $(r=0.69)$ (Figure 5), the separation between the Habanero peppers with respect to Jalapeño's and Serrano's can be observed, although it was not possible to identify between varieties within the same species or to identify an association between regions. Amorim et al. [36] found that the carotenoid content and the use of molecular markers in different genotypes of bananas, provided useful information on kin selection by crossing among different genotypes in order to develop new varieties with functional properties.

Our results could be influenced only by the RAPD because the carotenoid dendrogram did not show differences between species; however, this separation maintained between the species does not occur in the case of phenols. Therefore, the carotenoids are closely associated with molecular markers, specifically OPE 18.

\section{Conclusions}

The present study was able to establish a separation and differentiation between the chilli species C. annuum L. and C. chinense Jacq, through the RAPD molecular method by using different primers. Also, by chromatographic profiles of carotenoids and molecular markers in mature chilli peppers and amplification by oligonucleotide OPE 18, it was possible to distinguish between Habanero and Serrano/Jalapeño varieties, but no differences were found between $C$. annuum varieties. On the other hand, the PCA of phenolic compounds in peppers, showed four groups according to their place of origin. Hence this technique can be used to identify chilli varieties from different geographical areas, which might be used for the protection of rights in the variety, diversity and phylogenetic analysis, as well as for the confirmation of hybrids.

\section{Acknowledgments}

This paper was supported by the project SIP-IPN 20110329. The authors thank EDI, COFAA, and SNI. I. Troconis-Torres received a study Grant 215834 from the National Council of Science and Technology-Mexico (CONACYT).

\section{References}

[1] SARH (Secretaria de Agricultura y Recursos Hidráulicos) and INIA (Instituto Nacional de Investigaciones Agrícolas), "Presente y pasado del chile en México $1^{\text {a }}$ reimpresión," Tech. Rep. 85, Instituto Nacional de Investigaciones Agrícolas, Mexico City, Mexico, 1984.

[2] J. Pino, M. González, L. Ceballos et al., "Characterization of total capsaicinoids, colour and volatile compounds of Habanero chilli pepper (Capsicum chinense Jack.) cultivars grown in Yucatan," Food Chemistry, vol. 104, no. 4, pp. 16821686, 2007.

[3] F. Conforti, G. A. Statti, and F. Menichini, "Chemical and biological variability of hot pepper fruits (Capsicum annuumvar. acuminatum L.) in relation to maturity stage," Food Chemistry, vol. 102, no. 4, pp. 1096-1104, 2007.

[4] K. Sitthiwong, T. Matsui, S. Sukprakarn, N. Okuda, and Y. Kosugi, "Classification of pepper (Capsicum annuum L.) accessions by RAPD analysis," Biotechnology, vol. 4, no. 4, pp. 305-309, 2005.

[5] G. Oboh, R. L. Puntel, and J. B. T. Rocha, "Hot pepper (Capsicum annuum, Tepin and Capsicum chinese, Habanero) prevents $\mathrm{Fe}^{2+}$-induced lipid peroxidation in brain-in vitro," Food Chemistry, vol. 102, no. 1, pp. 178-185, 2007.

[6] K. Suna, T. YoulHa, and J. Park, "Characteristics of pigment composition and colour value by the difference of harvesting times in Korean red pepper varieties (Capsicum annuum, L.)," International Journal of Food Science and Technology, vol. 43, no. 5, pp. 915-920, 2008.

[7] A. Vega-Gálvez, K. Di Scala, K. Rodríguez et al., "Effect of air-drying temperature on physico-chemical properties, antioxidant capacity, colour and total phenolic content of red pepper (Capsicum annuum, L. var. Hungarian)," Food Chemistry, vol. 117, no. 4, pp. 647-653, 2009.

[8] D. Falk and K. Holsinger, Genetics and Conservation of Rare Plants, Oxford University Press, New York, NY, USA, 1991.

[9] J. G. K. Williams, M. K. Hanafey, J. A. Rafalski, and S. V. Tingey, "Genetic analysis using random amplified polymorphic DNA markers," Methods in Enzymology, vol. 218, pp. 704$740,1993$.

[10] N. Xena, "Una década de aplicación del método RAPD: alcances y limites en el estudio de relaciones genéticas en plantas," Acta Científica Venezolana, vol. 51, no. 4, pp. 197206, 2000. 
[11] P. Tapia and S. Legaria, "Variabilidad genética en cultivares de guayabo (Psidium guajava L.)," Revista Fitotecnia Mexicana, vol. 30, no. 4, pp. 391-401, 2007.

[12] M. Silva, L. Ming, A. Pereira, B. Bertoni, A. Batistini, and A. Pereira, "Phytochemical and genetic variability of Casearia sylvestris Sw. from Sao Paulo State Atlantic forest and Cerrado populations," Revista Brazileña de PIantas Medicinales, vol. 8, pp. 159-166, 2006.

[13] S. Ercisli, E. Orhan, O. Ozdemir, and M. Sengul, "The genotypic effects on the chemical composition and antioxidant activity of sea buckthorn (Hippophae rhamnoides L.) berries grown in Turkey," Scientia Horticulturae, vol. 115, no. 1, pp. 27-33, 2007.

[14] S. Ercisli, E. Orhan, N. Yildirim, and G. Ağar, "Comparison of sea buckthorn genotypes (Hippophae rhamnoides L.) Based on RAPD and FAME data," Turkish Journal of Agriculture and Forestry, vol. 32, no. 5, pp. 363-368, 2008.

[15] K. Aitzetmuller, "Capillary GLC fatty acid fingerprints of seed lipids-a tool in plant chemotaxonomy?" Journal of High Resolution Chromatography, vol. 16, no. 8, pp. 488-490, 1993.

[16] T. N. Füller, C. Tessele, I. B. I. Barros, and J. F. Barbosa Neto, "Phenotypical, phytochemical and molecular characterization of "capim-carona" [Elionurus muticus (Spreng.) Kuntze] populations," Revista Brasileira de Plantas Medicinais, vol. 12, no. 3, pp. 261-268, 2010.

[17] A. Rotini, C. Micheli, L. Valiente, and L. Migliore, "Assessment of Posidonia oceanica (L.) Delile conservation status by standard and putative approaches: the case study of Santa Marinella meadow (Italy, W Mediterranean)," Open Journal of Ecology, vol. 1, no. 2, pp. 48-56, 2011.

[18] C. Cordella, I. Moussa, A. C. Martel, N. Sbirrazzouli, and L. Lizzani-Cuvelier, "Recent developments in food characterization and adulteration detection: technique-oriented perspectives," Journal of Agricultural and Food Chemistry, vol. 50, no. 7, pp. 1751-1764, 2002.

[19] Normas Oficiales Mexicanas, "Productos alimenticios no industrializados para consumo humano-chile fresco (Capsicum spp)," Tech. Rep. NMX-FF-025-SCFI-2007, Normas Oficiales Mexicanas, Jalisco, Mexico, 2007.

[20] M. E. Jaramillo-Flores, J. J. Lugo-Martínez, E. RamírezSanJuan, H. Montellano-Rosales, L. Dorantes-Alvarez, and H. Hernández-Sánchez, "Effect of sodium chloride, acetic acid, and enzymes on carotene extraction in carrots (Daucus corota L.)," Journal of Food Science, vol. 70, no. 2, pp. S136-S142, 2005.

[21] A. Rodríguez, A Guide to Carotenoides Analysis in Foods, ILSI Press, Washington, DC, USA, 1999.

[22] K. K. Adom and R. H. Liu, "Antioxidant activity of grains," Journal of Agricultural and Food Chemistry, vol. 50, no. 21, pp. 6182-6187, 2002.

[23] T. Sun, Z. Xu, C. T. Wu, M. Janes, W. Prinyawiwatkul, and H. K. No, "Antioxidant activities of different colored sweet bell peppers (Capsicum annuum L.)," Journal of Food Science, vol. 72, no. 2, pp. S98-S102, 2007.

[24] B. Harbaum, E. M. Hubbermann, Z. Zhu, and K. Schwarz, "Free and bound phenolic compounds in leaves of pak choi (Brassica campestris L. ssp. chinensis var. communis) and Chinese leaf mustard (Brassica juncea Coss)," Food Chemistry, vol. 110, no. 4, pp. 838-846, 2008.

[25] A. Versari, G. P. Parpinello, F. Scazzina, and D. D. Rio, "Prediction of total antioxidant capacity of red wine by Fourier transform infrared spectroscopy," Food Control, vol. 21, no. 5, pp. 786-789, 2010.
[26] T. Allers and M. Lichten, "A method for preparing genomic DNA that restrains branch migration of Holliday junctions," Nucleic Acids Research, vol. 28, no. 2, pp. 1-7, 2000.

[27] J. Sambrook and D. Russell, Molecular Cloning: A Laboratory Manual, Cold Spring Harbor Lab Press, Cold Spring Harbor, NY, USA, 3rd edition, 2001.

[28] M. Hermosillo, J. González, S. Romero, M. Luján, A. Hernández, and S. Arévalo, "Relación genética de materiales experimentales de chile tipo chilaca con variedades comerciales," Revista de Chapingo Serie Horticultura, vol. 14, no. 3, pp. 301-307, 2008.

[29] A. Marín, F. Ferreres, F. A. Tomás-Barberán, and M. I. Gil, "Characterization and quantitation of antioxidant constituents of sweet pepper (Capsicum annuum L.)," Journal of Agricultural and Food Chemistry, vol. 52, no. 12, pp. 38613869, 2004.

[30] Z. Collera, G. Federico, and G. Meléndez, "Comparative study of carotenoid composition in three mexican varieties of Capsicum annuum L," Food Chemistry, vol. 90, no. 1-2, pp. 109-114, 2005.

[31] D. Zhang and Y. Hamauzu, "Phenolic compounds, ascorbic acid, carotenoides and antioxidant properties of green, red and yellow bell peppers," Journal of Food, Agriculture \& Environment, vol. 1, no. 2, pp. 22-27, 2003.

[32] N. Deepa, C. Kaur, B. George, B. Singh, and H. C. Kapoor, "Antioxidant constituents in some sweet pepper (Capsicum annuum L.) genotypes during maturity," Food Science and Technology, vol. 40, no. 1, pp. 121-129, 2007.

[33] H. Matsufuji, K. Ishikawa, O. Nunomura, M. Chino, and M. Takeda, "Anti-oxidant content of different coloured sweet peppers, white, green, yellow, orange and red (Capsicum annuum L.)," International Journal of Food Science and Technology, vol. 42, no. 12, pp. 1482-1488, 2007.

[34] G. F. Antonious, T. S. Kochhar, R. L. Jarret, and J. C. Snyder, "Antioxidants in hot pepper: variation among accessions," Journal of Environmental Science and Health, vol. 41, no. 7, pp. 1237-1243, 2006.

[35] S. Lanteri, A. Acquadro, L. Quagliotti, and E. Portis, "RAPD and AFLP assessment of genetic variation in a landrace of pepper (Capsicum annuum L.), grown in North-West Italy," Genetic Resources and Crop Evolution, vol. 50, no. 7, pp. 723735, 2003.

[36] E. P. Amorim, A. D. Vilarinhos, K. O. Cohen et al., "Genetic diversity of carotenoid-rich bananas evaluated by Diversity Arrays Technology (DArT)," Genetics and Molecular Biology, vol. 32, no. 1, pp. 96-103, 2009. 

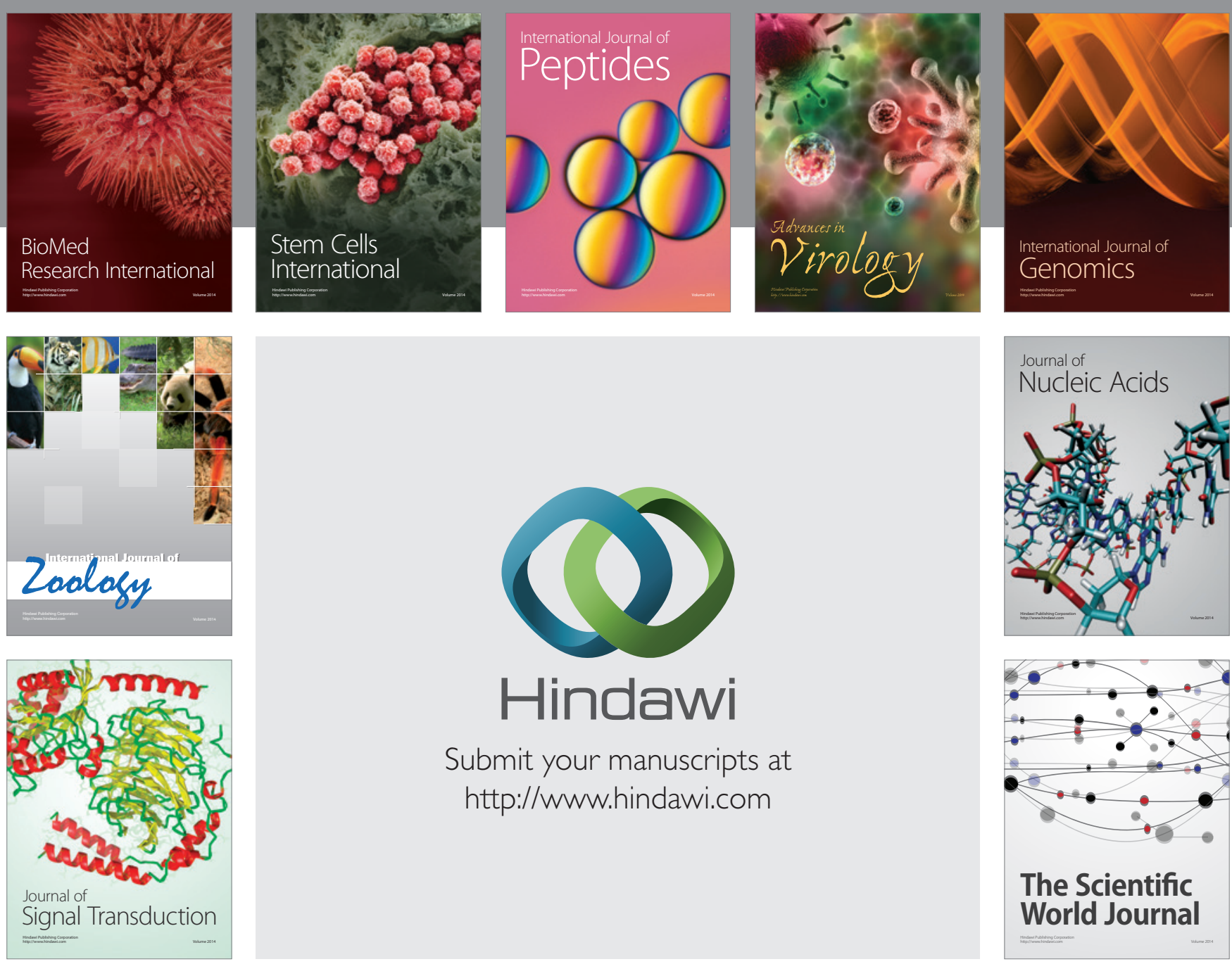

Submit your manuscripts at

http://www.hindawi.com
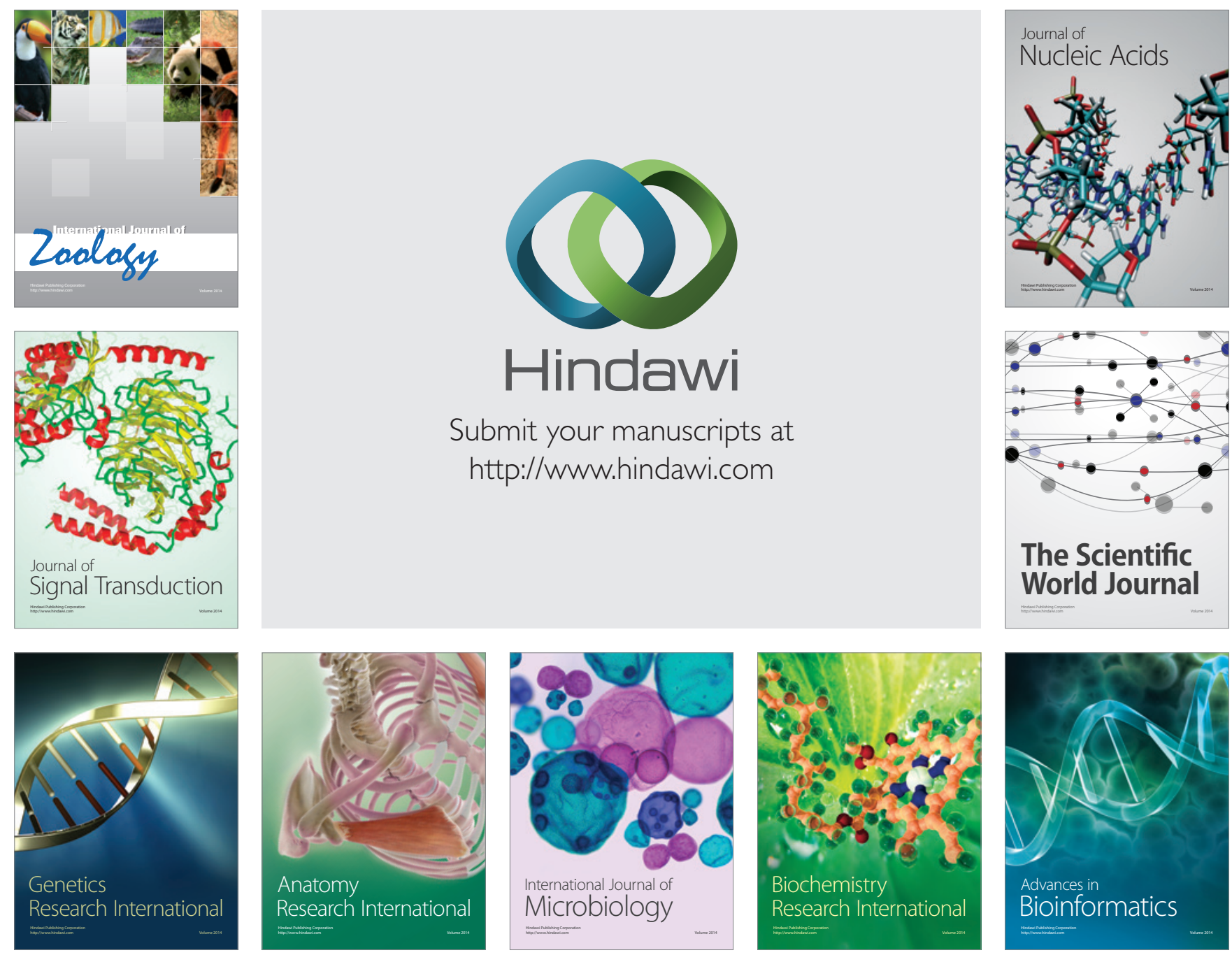

The Scientific World Journal
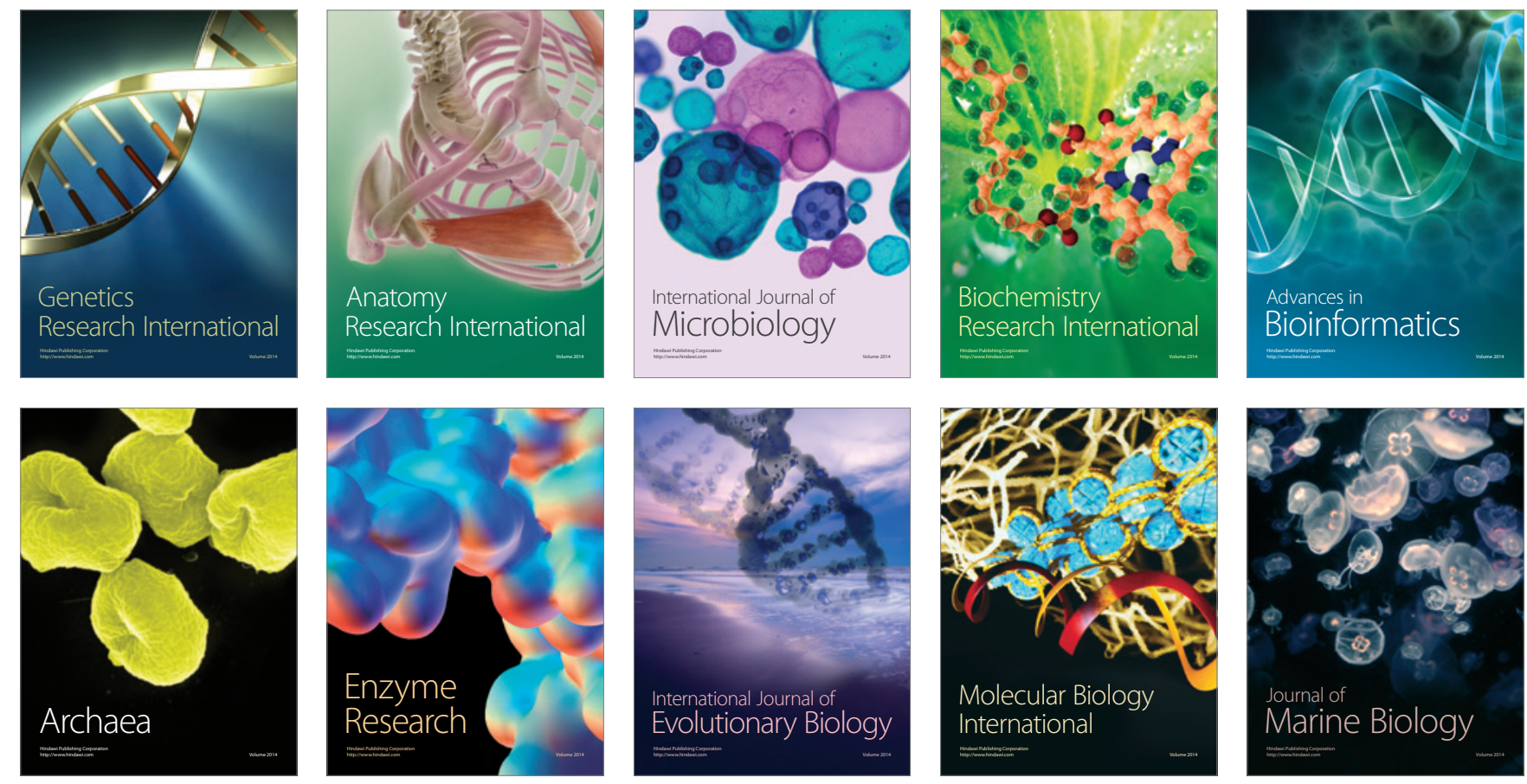